\title{
14- Covid-19 salgını sürecinde yayınlanan uzaktan eğitim konulu lisansüstü tezlerin incelenmesi
}

\section{Nahide İrem AZİZOĞLU1}

APA: Azizoğlu, N. ̇̇. (2021). Covid-19 salgını sürecinde yayınlanan uzaktan eğitim konulu lisansüstü tezlerin incelenmesi. RumeliDE Dil ve Edebiyat Araştırmaları Dergisi, (Ö10), 238-250. DOI: 10.29000/rumelide.1011400.

\section{$\ddot{O} \mathbf{z}$}

2020 yılı Ocak ayında başlayan ve hızla tüm dünyaya yayılan Covid-19 salgını ekonomi ve eğitim başta olmak üzere tüm alanları etkilemiştir. Salgının yayılmasını azaltmak amacıyla pek çok ülkede eğitime ara verilmiştir. Bu durumun eğitim sürecini aksatmaması için çözüm olarak uzaktan eğitim ile sürece devam edilmiştir. Uzaktan eğitim konusunun gündeme gelmesi ile bu alanda yapılan araştırmalarda artış olması mümkündür. Bu nedenle araştırmada salgın sürecinin başından 2021 yılı Eylül ayına kadar hazırlanmış olan lisansüstü tezlerin incelenmesi ve bu tezlerdeki araştırma eğilimlerinin belirlenmesi hedeflenmiştir. Araştırmada betimsel tarama yöntemi kullanılmıştır. Araştırma kapsamında incelenecek tezler belirlenirken uzaktan eğitim, uzaktan, çevrimiçi, çevrim içi, online, e-öğrenme anahtar kelimeleri kullanılarak Yüksek Öğretim Kurulu (YÖK) Tez Merkezi üzerinden tarama yapılmıştır. Bu tarama sonucunda araştırmaya 133 tez dâhil edilmiştir. İnceleme sonucunda tezlerin çoğunun yüksek lisans tezi olduğu, Türkçe olarak hazırlandığı, 2021 yılında daha fazla sayıda tezin hazırlandığı tespit edilmiştir. Uzaktan eğitim konusunda en fazla Gazi Üniversitesi bünyesinde lisansüstü tez hazırlanmış olup enstitü ve anabilim dalları açısından inceleme yapıldığında Eğitim Bilimleri Enstitüsü ile Bilgisayar ve Öğretim Teknolojileri Eğitimi Anabilim Dalı'nın öne çıktığı belirlenmiştir. Araştırma modeli olarak karma yöntem, örneklem grubu olarak öğrenciler, örnekleme yöntemi olarak amaçlı ve uygun örnekleme daha fazla tercih edilmiştir. Tezler konu açısından incelendiğinde teknoloji, öğretmen ve öğrenci eğitimi, uzaktan eğitimde duyuşsal beceriler, öğretim yöntemi konularının öne çıktığı tespit edilmiştir.

Anahtar kelimeler: Uzaktan eğitim, tez, Covid-19, eğitim

\section{Examination of theses on distance education prepared during the Covid-19 pandemic}

\begin{abstract}
The Covid-19 pandemic, which has started in January 2020 and rapidly spread all around the world, affected all activities, especially the economy and education. Many countries had to close the schools to reduce the pandemic's spread. As a solution, the process continued with distance education in order not to hinder the education. It is likely that research on this field increases as the distance education gains currency. That is why, the research aimed to examine the master's theses prepared from the beginning of the pandemic until September 2021 and determine the research tendencies in these theses. Descriptive survey method was used in the research. A survey on YÖK Thesis Center was conducted by searching the keywords distance education, distant, online, online, e-learning while determining the thesis that would be examined within the research. After the survey, a total of 133
\end{abstract}

Ars. Gör. Dr., Sakarya Üniversitesi, Eğitim Fakültesi, Türkce ve Sosyal Bilimler Eğitimi ABD (Sakarya, Türkiye), azizoglu@sakarya.edu.tr, ORCID ID: 0ooo-0oo3-2738-9856 [Áraştırma makalesi, Makale kayıt tarihi: 27.09.2021-kabul tarihi: 20.10.2021; DOI: 10.2900o/rumelide.1011400]

Adres

RumeliDE Dil ve Edebiyat Araşturmaları Dergisi Osmanağa Mahallesi, Mürver Çiçeği Sokak, No:14/8 Kadıköy - ISTANBUL / TÜRKIYE 34714 e-posta: editor@rumelide.com tel: +90 505 7958124, +90 2167730616

Addres

RumeliDE Journal of Language and Literature Studies

Osmanağa Mahallesi, Mürver Çiçeği Sokak, No:14/8

Kadıköy - ISTANBUL / TURKEY 34714

e-mail: editor@rumelide.com,

phone: +90 5057958124 , +90 2167730616 


\begin{abstract}
thesis we included in the study. As the research result, it was determined that most of the thesis were master's theses in Turkish and more theses were prepared in 2021. It was determined that the highest number of thesis on distance education were prepared at Gazi University. When it was examined according to institutes and departments, it was determined that Computer and Instructional Technologies Department stood out. Mixed methods were preferred as the research model, students as the sample, and purposive and convenience sampling as the sampling method. When the theses were examined, it was determined that topics of technology, teacher, teaching students, audial capabilities in distance learning, and teaching methods prevailed.
\end{abstract}

Keywords: Distance education, dissertation, Covid-19, education

\title{
Giriş
}

Teknolojinin hızla gelişmesi ve bu gelişim sonucunda bilgiye erişim olanaklarının artması ile birlikte öğretim sürecine uzaktan eğitim kavramı dâhil olmuştur. Günümüzde üniversiteler başta olmak üzere farklı kamu kurumları ve özel kurumlar uzaktan eğitim kullanmayı tercih edebilmektedir. Uzaktan eğitim genellikle akademik bir kurumdan uzakta, bireyin istediği ortamdan katılabileceği şekilde yapılandırılmış öğrenme süreci olarak tanımlanmaktadır. Uzaktan eğitim sonucunda kişi tıpkı örgün eğitim sürecinde olduğu gibi belirli bir derece ve yetkinliğe ulaşmaktadır (Gunawardena ve McIsaac, 2013; Özonur, 2021). Uzaktan eğitime ilişkin ilerlemelerin hızlandığı dönemin elektronik devrim olarak nitelendirilebilecek gelişmelerin gerçekleştiği $1980^{\prime} l e r$ olduğu bilinmektedir. Uzaktan eğitim teknolojik gelişmelerden, sanayi devrimi ile ilişkilendirilen bilginin aktarımı ve paylaşımı teknolojilerinden bağımsız olarak düşünülemez. Uzaktan eğitimi örgün eğitimden ayıran, yüz yüze iletişimin yerini teknolojik araçların alması ve öğretmen ile öğrenenin, öğrenen ile öğrenme grubu ve ortamının birbirinden ayrı olmasıdır. Bu nedenle uzaktan eğitim herhangi bir zamanda ve mekânda öğrenci sayısından bağımsız olarak ders verilmesidir (Keegan, 2013; Wedemeyer, 1981).

Eğitim süreçleri her zaman dönemin teknolojik yapısına paralel olarak ilerleme göstermektedir. Tüm eğitim süreçlerinde öğretmen, öğrenci ve içerik değişkenleri sabit olarak bulunsa da bu değişkenler arasındaki ilişkilerin gelişimi öğretim sürecinde belirleyici rol oynamaktadır (Anderson ve Dron, 2011; Sezgin ve Frrat, 2020). Covid-19 salgın süreci öncesinde genellikle üniversiteler uzaktan eğitimi kullanarak ön lisans, lisans, lisansüstü eğitimler ve sertifika programları uygulamaktaydı. Bu eğitimlerin bazıları hibrit (yüz yüze ve uzaktan eğitim birlikte) bazıları ise sadece uzaktan eğitim şeklinde yürütülmüştür. Bu süreçlerde online ortamlarda ders materyalleri, ders içerikleri, notların paylaşımı tercih edilmiştir. Buradan hareketle uzaktan eğitim süreci öğrenmenin gerçekleşmesi amaciyla birbirinden farklı yöntemlerin ve materyallerin online ortamlarda sunulmasına dayanan bir öğretim ortamı olarak açılanabilir (Simonson, Zvacek ve Smaldino, 2019).

Uzaktan eğitim yaygınlaşmasına rağmen uygulama sürecine ilişkin bazı sorunlar devam etmektedir. Uzaktan eğitim sürecinde çoğu öğretmenin ve yöneticinin kullanımına hâkim olmadığı eğitim teknolojilerinin gerekmesi, öğretmenin sadece eğitimci rolünde değil aynı zamanda danışman, konu uzmanı, yönetici, iletişim uzmanı görevleri üstlenmesi eğitimci açısından yorucu ve zorlayıcı olabilir. Bu durumun yanı sıra uzaktan eğitimin planlama, geliştirme, üretme ve dağıtım gerektiren özel bir uzmanlık alanı olması uygulamada aksaklıklara neden olmaktadır. Bu durumlar uzaktan eğitimin etkililiğinin sorgulanmasına neden olmaktadır (Moore ve Thompson, 1990: 9). Threlkeld ve Brzoska (1994) uzaktan eğitimin eğitim kalitesini azaltmadığını ve yüz yüze eğitime oranla ekonomik olarak kolaylıklar sunduğunu belirtmektedir. Uzaktan eğitimin kalitesi öğrenci, öğretim sürecinde sunulan

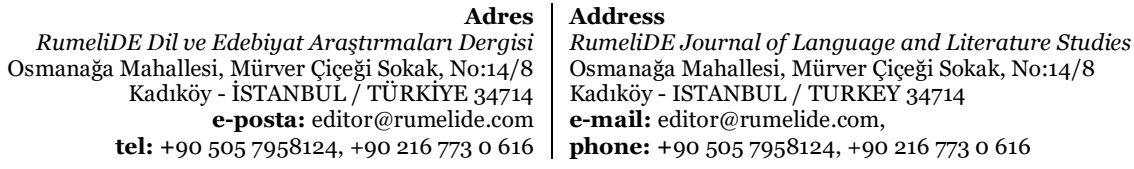


destek, bireylerin motivasyon ve ihtiyaçları, öğretimin nasıl tasarlandığı değişkenleri ile ilişkilidir. Bu değişkenler uzaktan eğitim açısından incelendiğinde ve programlar buna uygun şekilde hazırlandığında uzaktan eğitim sürecinin verimi de artacaktır. Persico, Manca ve Pozzi (2014) uzaktan eğitimde sistem yönetiminin, eğitim sisteminin ve kullanılan kaynakların, eğitimcilerin bilgi ve becerilerinin, pedagojik yaklaşımların, öğrenenlerin bilişsel ve duyuşsal özelliklerinin sürecin niteliğini etkilediğini ifade etmektedir.

Uzaktan eğitimi sadece kurumların ve öğretmenlerin hazır olmaları ile sinırlandırmak mümkün değildir. Yüz yüze eğitim almaya alışkın olan öğrencilerin uzaktan eğitime hazırbulunuşlukları, tutumları sürecin etkililiğini ve verimini etkileyecektir (Yakar ve Ylldırım Yakar, 2021). Lee ve Rha (2009: 372) uzaktan eğitim sürecinde en önemli değişkenin öğretim programı olduğunu belirtmektedir. Etkili ve verimli öğrenmeyi sağlamak için öğretim programlarının nasıl tasarlanacağı, geliştirileceği ve uygulanacağı uzaktan eğitimi etkileyen en önemli unsurdur. İnsanlık tarihinde eğitim süreçleri incelendiğinde yüz yüze eğitimin ön planda olduğu görülmektedir. Bu nedenle uzaktan eğitim olağanüstü ve sıra dışı bir uygulama olarak nitelendirilmektedir. Bu sorunu ortadan kaldırılmasının yolu öğretim programının uzaktan eğitim ile bireyler arasında köprü görevi üstlenmesinden geçmektedir.

Uzaktan eğitim öğrenciye istediği zaman diliminde istediği ortamdan eğitim alma, kendi çalışma düzenini oluşturma, okula gitmeden eğitim alma, sorunlarını internet ortamında çözebilme olanakları sunarken kişiler arası etkileşimi azaltma, öğretmenlerle iletişim sorunları, öğrencilerin kendi çalışma düzenlerini oluşturmakta zorlanmaları, bazı konuların öğretiminde zorlukların yaşanması, öğrencilerin motivasyonlarının olumsuz etkilenmesi gibi farklı sorunlara neden olabilmektedir. Bu sorunların ortadan kaldırılması için öğretmenlerin ve öğrencilerin uzaktan eğitim teknolojilerine ilişkin yeterli bilgiye sahip olmaları, öğretmenlerin konuya ilişkin yeterli pedagojik donanıma sahip olmaları, öğrenen ve öğretenin sürece ilişkin motivasyonlarının arttırılması, öğretim materyallerinin yeterli olması, yeterli teknik desteğin sağlanması önemlidir (Fojtík, 2018: 16).

Uzaktan eğitim salgın dönemi öncesinde sıra dışı ve yenilikçi bir uygulama olarak nitelendirilse de salgın süreci ile birlikte bir zorunluluk halini almıştır. Covid-19 salgınının 11 Mart 2020'de Dünya Sağllk Örgütü (DSÖ) tarafından küresel çapta salgın olarak nitelendirilmesi bu süreci başlatmıştır. Covid-19 sebebiyle Eylül 2021 tarihinde Türkiye'de yedi milyona yakın vaka olması (WHO, 2021) karantina süreçlerini ve eğitimin aksamasını beraberinde getirmiştir. Salgının yayılımının eğitimi aksatması nedeniyle UNESCO'nun tespit ettiği üzere virüsün görüldüğü tüm ülkelerde eğitimde aksaklıklar yaşanmış, eğitim belirli bir süreliğine ya da tamamen durdurulmuştur (Huang, Liu, Tlili, Yang ve Wang, 2020).

Salgının yayılım hızındaki artış sonucunda tüm eğitim kurumları uzaktan eğitime geçmek zorunda kalmıştır. Daha öncesinde farklı uygulamalar ve çalışmalar yapılsa da yeterli hazırlık yapılmadan uzaktan eğitim bir zorunluluk haline gelmiştir (Yamamoto ve Altun, 2020). Bu durum sonucunda tüm ülkeler eğitimde sürekliliği sağlamak adına çeşitli çözüm yolları belirlemiştir. Türkiye'de uzaktan eğitim süreci 23 Mart 2020 tarihinde başlamış, internet ve televizyon kanalları üzerinden tüm kademelerde öğretime devam edilmiştir. Millî Eğitim Bakanlığı destekli Eğitimde Bilişim Ağı (EBA), EBA TV İlkokul, EBA TV Ortaokul ve EBA TV Lise olmak üzere 3 farklı televizyon kanalı ve 'eba.gov.tr', internet uygulamaları, okulların uzaktan eğitim sistemleri bu eğitim sürecinde kullanılmıştır. Erişim sorunu yaşayan öğrenciler için EBA ve Mobil destek noktaları oluşturularak uygulamaya destek sağlanmıştır (MEB, 2021).

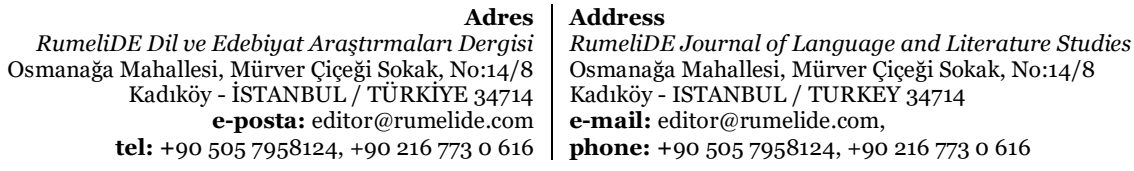


Salgın sürecinde ülkeler eğitim sorununu çözmek amacıyla farklı uygulamalar tercih etmişlerdir. Ancak bu uygulamalarda ön plana çıkan sorun erişim ve etkililik problemleri olmuştur. Özellikle ülkeler arasında ve ülke içinde gelir seviyelerindeki farklllıklar uzaktan eğitimin benimsenme ve kullanılma düzeyinde farklılıklara sebep olmaktadır (Karadă̆, Çiftçi, Gök, Su, Ergin Kocatürk ve Çiftçi, 2021: 9). Dünyada Covid-19 salgının eğitimde neden olduğu aksaklıklar her bireyi farklı biçimde etkilemiştir. Bu süreç eğitim özelinde ele alındığında öğrencilerin evlerinde sahip oldukları internet ve bilgisayara erişim olanakları, velilerin eğitim düzeyi, ülkeler arasındaki altyapı ve uzaktan eğitime aşinalık farklılıkları, öğrenciler arasındaki dijital okuryazarlık farklılıkları, ölçme ve değerlendirme problemleri (Özer ve Suna, 2020) süreci sekteye uğratan durumlara neden olmuştur. Covid-19 salgın sürecine ilişkin tahminlerin yapılamaması ve eğitime bu durumun nasıl yansıyacağının belirsizliği uzaktan eğitimin bu dönem ile sınırlı kalmayacağını ve gelecekte de devam edeceğini işaret etmektedir. Bu nedenle uzaktan eğitime ilişkin kalıcı ve sistematik uygulamaların hayata geçirilmesi önemlidir. Uzaktan eğitim sürecine hazırlıksız olarak başlamak, süreçteki aksaklıkların ve yetersizliklerin giderilememesi öğrencilerin eğitim sürecinde eksik kalmalarına neden olacağından çözüm odaklı hızlı tedbirlerin alınması gereklidir (Erzen ve Ceylan, 2020: 231).

Uzaktan eğitim konusunun gündeme gelmesi ile birlikte bu konuda yapılan çalışmalar ve değerlendirmeler artmıştır. Solmaz ve Gökçearslan (2016) mobil öğrenme kavramı üzerine yapılan lisansüstü tezleri inceleyerek 2010 yılı sonrasında bu konuya ilişkin çalışmaların arttığını tespit etmiştir. Ayrıca lisans öğrencilerine odaklanan daha fazla araştırmanın olduğu, betimsel istatistiklerin ve içerik analizinin daha fazla kullanıldığı bulunmuştur. Konuya ilişkin en fazla araştırma Gazi Üniversitesi bünyesinde yapılmıştır ve Bilgisayar ve Öğretim Teknolojileri Eğitimi anabilim dalı öne çımaktadır. Gökmen, Uysal, Yaşar, Kırksekiz, Güvendi ve Horzum (2017) uzaktan eğitim tezlerindeki yöntemsel eğilimleri inceleyerek tezlerde nicel araştırma yöntemlerinden en fazla tarama deseninin kullanıldığını, nitel araştırma yöntemlerinden ise durum çalışmasının daha fazla kullanıldığını tespit etmişlerdir. Ilgaz (2018) çevrimiçi öğrenme araştırmalarını bireysel farklılıklar açısından incelemiş ve en fazla akademik başarı değişkeninin çalışmalarda ele alındığını, bunun yanı sıra motivasyon, memnuniyet, kişilik özellikleri, teknoloji kabul, performans değişkenlerine de araştırmalarda yer verildiğini belirlemiştir. Aydoğdu (2019) mobil öğrenme konulu araştırmalarda nicel yöntemlerin, örneklem grubu olarak lisans öğrencilerinin, dil ve tıp eğitimi konularının daha sık yer aldığını tespit etmiş ve araştırma sayısında artış olduğunu ifade etmiştir. Uygun ve Sönmez (2019) mobil öğrenme konulu araştırmaları inceleyerek bu araştırmalarda genellikle lisans öğrencilerinin katılımcı olduğu, nicel araştırmaların tercih edildiği sonucuna ulaşmıştır. Mobil öğrenme üzerine bir diğer araştırma Korucu ve Biçer (2019) tarafından yürütülmüş̧tür. Araştırma sonucunda mobil öğrenme konulu çalışmaların araştırma konularının en çok mobil öğrenme hakkında değerlendirme yapma üzerine olduğu, nitel yöntemlerin daha sık kullanıldı̆̆ ve örneklem grubu olarak lisans öğrencilerinin öne çıtı̆̆ı tespit edilmiştir. Erdem Aydın, Kaya, İşkol ve İşcan (2019) araştırmalarında Anadolu Üniversitesi Uzaktan Eğitim Bölümü'nde hazırlanan lisansüstü tezleri incelemişlerdir. Araştırma sonucunda yüksek lisans tezlerinin daha fazla olduğu, tezlerin çoğunun öğretim ortamına odaklandığı ve nicel araştırma yöntemlerinin daha fazla tercih edildiği tespit edilmiştir. Parlakkılıç ve Güldüren (2019) tarafından hazırlanan bir diğer araştırmada Türkiye'de eöğrenme alanındaki eğilimler incelenmiş ve araç-içerik odaklı konuların ela alındığı, nicel araştırma yöntemlerinin tercih edildiği saptanmıştır. Delen (2021) e-öğrenme konulu tezlerde yüksek lisans tezlerinin fazla olduğunu belirleyerek genel tarama yönteminin tercih edildiğini ifade etmiştir. Üniversiteler açısından ele alındığında Gazi Üniversitesi, Hacettepe Üniversitesi ve Anadolu Üniversitesi bünyesinde daha fazla araştırma yürütülmüştür. Eğitim Bilimleri Enstitüsü ve Bilgisayar ve Öğretim Teknolojileri Eğitimi Anabilim Dalı bu konuda yürütülen araştırmalarda öne çlkmaktadır. Tezlerde yarı deneysel model ve ilişkisel tarama modeli daha fazla kullanılmış olup örneklem grubu

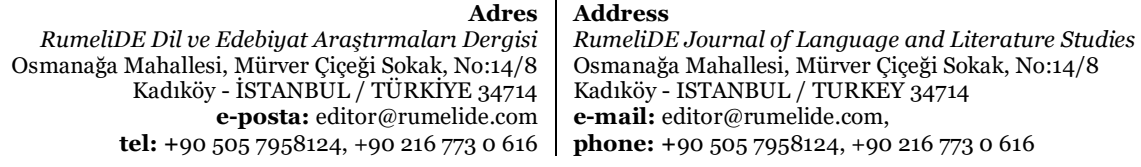


açısında ise lisans öğrencileri çoğu tezin örneklem grubunu oluşturmaktadır. Konuya ilişkin yapılan araştırmalarda farklı sonuçlar elde edildiği görülmektedir. Salgın sürecinde uzaktan eğitim konusunun gündeme yerleşmesi ile birlikte bu konuda yapılan lisansüstü çalışmalarda artış olmuştur. Bu nedenle araştırmanın amacı "Covid-19 salgın döneminde hazırlanan uzaktan eğitim konulu lisansüstü tezlerin incelenmesi" olarak belirlenmiştir. Araştırmada şu sorulara cevap aranmaktadır:

1. Covid-19 salgını döneminde yayınlanan lisansüstü tezlerin yl, yazım dili, tez türü, üniversite, enstitü ve anabilim dalına göre dağılımı nedir?

2. Covid-19 salgını döneminde yayınlanan lisansüstü tezlerin araştırma yöntemi, örneklem ve örnekleme yöntemine göre dağılımı nedir?

3. Covid-19 salgını döneminde yayınlanan lisansüstü tezler anahtar kelimeler ve başlıklara göre hangi konuları kapsamaktadır?

\section{Yöntem}

\section{Araştırmanın modeli}

Araştırmada Covid-19 salgın döneminde hazırlanan lisansüstü tezlerin incelenmesi amaçlandığından betimsel tarama yöntemi kullanılmıştır. Betimsel araştırmalar, bir durumu tanımlamaya yöneliktir. Eğitim alanında yapılabilecek betimsel çalışmalar çeşitli grupların başarılarını belirlemek, öğretmenlerin, yöneticilerin ya da danışmanların davranışlarını tanımlamak, ebeveynlerin tutumlarını ve okulun fiziki şartlarını tanımlamak olabilir. Olgunun tanımlanması tüm araştırma gayretlerinin başlangıç noktasıdır (Büyüköztürk, Çakmak, Akgün, Karadeniz ve Demirel, 2014: 22).

\section{Verilerin toplanması ve analizi}

Araştırmada Covid-19 salgın sürecinde uzaktan eğitimi konu edinen lisansüstü tezlerin incelenmesi hedeflendiğinden ilk aşamada YÖK Ulusal Tez Merkezi'nden konu ile ilişkili tezler taranmıştır. Salgın süreci 2020 yllı Ocak ayında başladığından uzaktan eğitim konusunun bu süreçte ön plana çıktığı belirtilebilir. Bu dönemde uzaktan eğitim konusunun gündemde olması sebebiyle hazırlanan lisansüstü tez sayısında artış olmuştur. Bu nedenle araştırmada Covid-19 salgın sürecini kapsayacak şekilde 2020 yılı Ocak ayı ile 2021 yılı Eylül ayı arasındaki süreçte hazırlanmış tezler ele alınmıştır. Tarama esnasında "uzaktan eğitim", "uzaktan", "çevrimiçi", "çevrim içi", "online", "e-öğrenme" anahtar kelimeleri kullanılmıştır. "Uzaktan eğitim" kelimeleri ile yapılan taramada 54, "uzaktan" kelimesi ile yapılan taramada 16, "çevrimiçi" kelimesi ile yapılan taramada 38, "e-öğrenme" kelimesi ile yapılan taramada 10, "online" kelimesi ile yapılan taramada 9, "çevrim içi" kelimesi ile yapılan taramada 6 lisansüstü teze ulaşılmıştır. "Uzaktan eğitim" ve "online" kelimeleri kullanılarak yapılan taramada iki tezin erişime kapalı olduğu tespit edilmiştir. Tez yazarları ile iletişime geçilmiştir. Ancak mevcut tezlere ulaşılamadığından araştırmada toplamda 133 tez incelenmiştir.

İncelenen tezler tez numarası, yazar, tez adı, yl, üniversite, enstitü, anabilim dalı, tezin dili, tez düzeyi, örneklem grubu, örnekleme yöntemi, araştırma yöntemi, anahtar kelimeler başlıkları altında incelendiğinden belirtilen veriler Excel-2013 dosyasına aktarılmış ve analizler bu dosya üzerinden yapılmıştır.

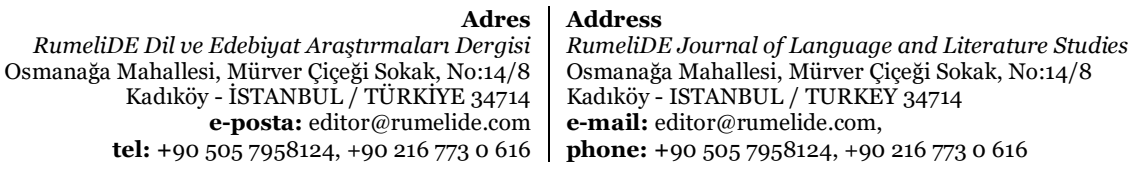

RumeliDE Journal of Language and Literature Studies

Osmanağa Mahallesi, Mürver Çiçeği Sokak, No:14/8

Kadıköy - ISTANBUL / TURKEY 34714

e-mail: editor@rumelide.com tel: +90 505 7958124, +90 216773 o 616 phone: +90 505 7958124, +90 2167730616 


\section{Bulgular}

\section{Salgın döneminde hazırlanan lisansüstü tezlerin yıl, yazım dili, tez türü, üniversite, enstitü, anabilim dalına göre dağılımı}

Covid-19 salgın sürecinde hazırlanan uzaktan eğitimi konu edinen lisansüstü tezlerin yllara ve tez türüne göre dağılımı Tablo 1'de verildiği gibidir.

Tablo 1. Uzaktan eğitim konulu lisansüstü tezlerin yıllara ve tez türüne göre dağılımı

\begin{tabular}{lllll}
\hline Yıl & Yüksek lisans tezi & & Doktora Tezi & \\
& İngilizce & Türkçe & İngilizce & Türkçe \\
\hline 2020 & 7 & 31 & 4 & 16 \\
2021 & 16 & 44 & 3 & 12 \\
\hline
\end{tabular}

Tablo 1 incelendiğinde 2020 yllında uzaktan eğitim konulu 38 yüksek lisans, 20 doktora tezinin; 2021 ylında ise 60 yüksek lisans 15 doktora tezinin hazırlandığ 1 görülmektedir. 2020 yllında bu konuda toplam 58, 2021 ylında ise toplam 75 lisansüstü tez bulunmaktadır. Yüksek lisans tezlerinin 23'ü, doktora tezlerinin 7 'si İngilizce olarak hazırlanmıştır. Türkçe ve İngilizceden farklı dilde hazırlanan tez bulunmamaktadır.

Uzaktan eğitimi konu alan lisansüstü tezlerin üniversitelere göre dağılımı Tablo 2'de verilmiştir.

Tablo 2. Uzaktan eğitim konulu lisansüstü tezlerin üniversitelere göre dağılımı

\begin{tabular}{llll}
\hline Üniversite & Tez sayısı & Üniversite & Tez sayısı \\
\hline Gazi Üniversitesi & 14 & Maltepe Üniversitesi & 3 \\
Bahçeşehir Üniversitesi & 12 & Ondokuz Mayı Üniversitesi & 3 \\
Anadolu Üniversitesi & 8 & Sakarya Üniversitesi & 3 \\
ODTü & 6 & Abant İzzet Baysal Üniversitesi & 2 \\
Atatürk Üniversitesi & 5 & Ege Üniversitesi & 2 \\
Hacettepe Üniversitesi & 5 & İstanbul Teknik Üniversitesi & 2 \\
Necmettin Erbakan Üni. & 5 & Kastamonu Üniversitesi & 2 \\
Inönü Üniversitesi & 4 & Kocaeli Üniversitesi & 2 \\
Osmangazi Üniversitesi & 4 & Osmaniye Korkut Ata Üni. & 2 \\
Ufuk Üniversitesi & 4 & Recep Tayyip Erdoğan Üni. & 2 \\
Ankara Üniversitesi & 3 & Trabzon Üniversitesi & 2 \\
Bartın Üniversitesi & 3 & Yeditepe Üniversitesi & 2 \\
Gaziantep Üniversitesi & 3 & Ylldı Teknik Üniversitesi & 2 \\
Fırat Üniversitesi & 3 & Diğer üniversiteler* & \\
\hline
\end{tabular}

*Adnan Menderes, Afyon Kocatepe, Akdeniz, Amasya, Arel, Başkent, Celal Bayar, Çă̆, Çanakkale 18 Mart, Erzincan Binali Yıldırım, Fatih Sultan Mehmet Vakıf, Giresun, İstanbul, İstanbul Aydın, İstanbul Bilgi, İstanbul Kültür, İzmir Kâtip Çelebi, Karadeniz Teknik, Mardin Artuklu, Mehmet Akif Ersoy,

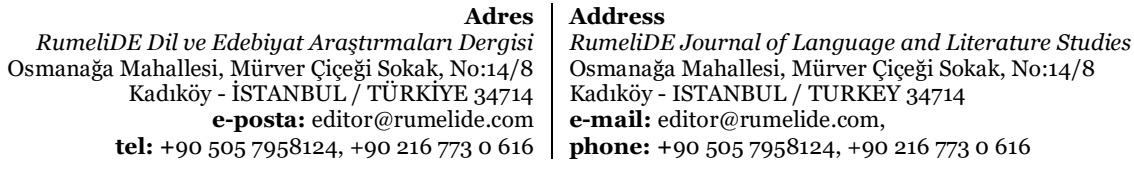


Mimar Sinan Güzel Sanatlar, Muş Alparslan, Sabahattin Zaim, Uşak, Yüzüncü Yıl Üniversiteleri'nde 1 uzaktan eğitim konulu lisansüstü tez bulunmaktadır.

Tablo 2 incelendiğinde 2020-2021 ylllarında uzaktan eğitim konusunda en fazla lisansüstü tezin Gazi Üniversitesi'nde hazırlandığı görülmektedir. Bahçeşehir Üniversitesi'nde 12, Anadolu Üniversitesi'nde 8, Orta Doğu Teknik Üniversitesi'nde 6 uzaktan eğitim konulu lisansüstü tez hazırlanmıştır. Bu üniversitelerin dışında 48 farklı devlet ve vakıf üniversitesinde uzaktan eğitim konusunda araştırma yapıldı̆̆ tespit edilmiştir.

Uzaktan eğitimi konulu lisansüstü tezlerin hazırlandıkları enstitülere göre dağılımı Tablo 3'te yer almaktadır.

Tablo 3. Uzaktan eğitim konulu lisansüstü tezlerin enstitülere göre dağılımı

\begin{tabular}{ll}
\hline Enstitü & Tez sayısı \\
\hline Eğitim Bilimleri Enstitüsü & 58 \\
Sosyal Bilimler Enstitüsü & 34 \\
Lisansüstü Eğitim Enstitüsü & 21 \\
Fen Bilimleri Enstitüsü & 16 \\
Sağllk Bilimleri Enstitüsü & 3 \\
Güzel Sanatlar Enstitüsü & 1 \\
\hline
\end{tabular}

Tablo 3 incelendiğinde 2020-2021 ylllarında uzaktan eğitim konusunda en fazla tezin Eğitim Bilimleri Enstitüsü'nde hazırlandığı görülmektedir. Ayrıca Sosyal Bilimler, Lisansüstü Eğitim, Fen Bilimleri, Sağlık Bilimleri, Güzel Sanatlar Enstitüsü'nde uzaktan eğitim konusunda hazırlanan lisansüstü tezler tespit edilmiştir.

Uzaktan eğitimi konulu lisansüstü tezlerin hazırlandıkları anabilim dalına göre dağılımı Tablo 4'te verildiği gibidir.

Tablo 4. Uzaktan eğitim konulu lisansüstü tezlerin anabilim dallarına göre dağılımı

\begin{tabular}{llll}
\hline Anabilim dalı & Tez sayısı & Anabilim dalı & Tez sayısı \\
\hline Bilgisayar ve Öğretim Teknolojileri Eğt. & 25 & Temel Eğitim & 5 \\
Eğitim Bilimleri & 23 & İşletme & 4 \\
Yabancı Diller Ĕ̆itimi & 9 & Bilgisayar Mühendisliği & 4 \\
İngiliz Dili Eğitimi & 9 & Eğitim Teknolojisi & 3 \\
Uzaktan Eğitim & 8 & Beden Eğitimi ve Spor & 2 \\
Türkçe ve Sosyal Bilimler Eğitimi & 6 & Yönetim Bilişim Sistemleri & 2 \\
Güzel Sanatlar & 5 & Diğer anabilim dalları* & \\
Matematik ve Fen Bilimleri Eğitimi & 5 & & \\
\hline
\end{tabular}

*Batı Dilleri ve Edebiyatları, Bilgisayar, Biyoloji, Deniz Ulaştırma Mühendisliği, Çocuk Gelişimi ve Eğitimi, Eğitsel Tasarım ve Değerlendirme, Endüstri Mühendisliği, Enformatik, Felsefe ve Din Bilimleri, Fizyoterapi ve Rehabilitasyon, Görsel İletişim, Hemşirelik Esasları, Hemşirelikte Öğretim, Medya ve İletişim Sistemleri, Moda Tasarımı, Özel Eğitim, Rehberlik ve Psikolojik Danışmanlık, Siyaset Bilimi ve Kamu Yönetimi, Tarih, Türkçe Eğitimi, Yabancı Dil Olarak Türkçe, Yazılım Mühendisliği, 
Yükseköğretimin Yönetimi ve Politikası anabilim dallarında 1 uzaktan eğitim konulu lisansüstü tez hazırlanmıştır.

Tablo 4 incelendiğinde uzaktan eğitim konusunda en fazla Bilgisayar ve Öğretim Teknolojileri Anabilim Dalı'nda lisansüstü tez çalışması yapıldığı görülmektedir. Eğitim Bilimleri Anabilim Dalı'nda 23, Yabancı Diller Eğitimi ve İngiliz Dili Eğitimi Anabilim Dahı'nda toplam 18, Uzaktan Eğitim Anabilim Dalı'nda 8, Türkçe ve Sosyal Bilimler Eğitimi Anabilim Dalı'nda 6 uzaktan eğitim konulu lisansüstü tez hazırlanmıştır. Bunların dışında 30 farklı anabilim dalında bu konuda lisansüstü tezlerin hazırlandığı tespit edilmiştir.

Salgın döneminde hazırlanan lisansüstü tezlerin araştırma yöntemi, örneklem grupları, örnekleme yöntemine göre dağılımı

Salgın sürecinde hazırlanan uzaktan eğitim konulu lisansüstü tezler incelendiğinde 14 tezde araştırma yönteminin açıklanmadığı tespit edilmiştir. 119 lisansüstü tezde araştırma yöntemi belirtildiği tespit edilmiş ve bunlara ilişkin bulgular Tablo 5 'te verilmiştir.

Tablo 5. Uzaktan eğitim konulu lisansüstü tezlerin araştırma yöntemleri

\begin{tabular}{llll}
\hline Araştırma yöntemi & Tez sayısı & Araştırma yöntemi & Tez sayısı \\
\hline Karma yöntem & 30 & Nedensel karşılaştırma araştırması & 2 \\
Betimsel tarama & 21 & Nitel araştırma & 2 \\
Durum çalışması & 19 & Nicel araştırma & 1 \\
İlişkisel tarama & 13 & Nicel karışık desen & 1 \\
Yarı deneysel desen & 9 & Çoklu yoklama deseni & 1 \\
Olgubilim & 6 & Faktöriyel desen & 1 \\
Tasarım tabanlı & 5 & Metasentez & 1 \\
araştırma & 4 & Gömülü teori & 1 \\
$\begin{array}{l}\text { Eylem araştırması } \\
\text { Öntest sontest kontrol } \\
\text { gruplu deneysel desen }\end{array}$ & 2 & & \\
\hline
\end{tabular}

Tablo 5 incelendiğinde salgın döneminde tamamlanmış lisansüstü tezlerde en fazla karma yöntem araştırması yapıldığı görülmektedir. Betimsel tarama 21, durum çalışması 19, ilişkisel tarama 13, yarı deneysel desen 9, olgubilim 6, tasarım tabanlı araştırma 5, eylem araştırması 4 lisansüstü tezin yöntemini oluşturmaktadır. Bunun dışında 9 farklı araştırma yöntemine tezlerde yer verilmiştir.

Salgın sürecinde hazırlanan uzaktan eğitim konulu lisansüstü tezlerin örneklemleri incelendiğinde örneklem grubu belirtilmesi gereken araştırma yönteminin kullanıldığı ancak örneklem grubunun açıklanmadığı 1 lisansüstü tez tespit edilmiştir. 20 tezde birbirinden farklı örneklem grupları bulunduğundan bu tezlerde yer alan her bir grup ayrı ayrı işleme alınmıştır. Uzaktan eğitim konulu lisansüstü tezlerin örneklem gruplarına ilişkin bulgular Tablo 6'da verildiği gibidir.

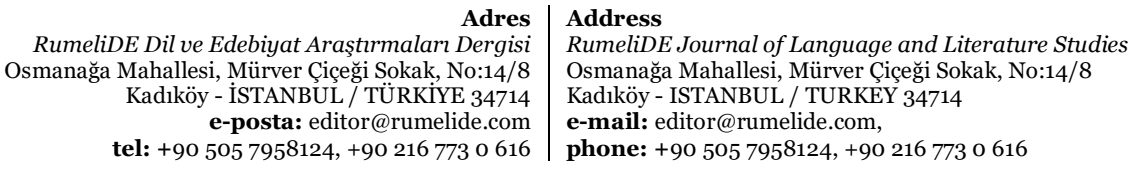


Tablo 6. Uzaktan eğitim konulu lisansüstü tezlerin örneklemleri

\begin{tabular}{llll}
\hline Örneklem & Tez sayısı & Örneklem & Tez sayısı \\
\hline Öğrenci (ilkokul, ortaokul, lise) & 44 & Engelli bireyler & 2 \\
Öğretmen & 36 & Sağlık çalı̧anları & 2 \\
Üniversite öğrencisi & 21 & Uzman & 2 \\
Akademisyen & 18 & İşletmeci & 1 \\
Öğrenci velileri & 7 & Hemşire & 1 \\
Katıllımcı & 8 & Memur & 1 \\
Yönetici & 5 & & \\
\hline
\end{tabular}

Tablo 6 incelendiğinde örneklem belirtilen uzaktan eğitim konulu lisansüstü tezlerde en fazla araştırmanın öğrencilerle yürütüldüğü görülmektedir. Öğretmenlerin örneklem grubunda yer aldığı 36, lisans öğrencilerinin örneklem grubunda yer aldığı 21, akademisyenlerin örneklem grubunda yer aldığı 18 lisansüstü tez bulunmaktadır. Bunların dışında 9 farklı kategoride örneklem grubu tezlerde yer almaktadır.

Salgın sürecinde hazırlanan uzaktan eğitimi konulu lisansüstü tezlerin örnekleme yöntemleri incelendiğinde 46 lisansüstü tezde örnekleme yönteminin yazılmadığı ve 26 tezde evren-örneklem belirlemek yerine çalışma grubu seçildiği tespit edilmiştir. Geriye kalan 61 lisansüstü tezin örnekleme yöntemlerine ilişkin bulgular Tablo 7'de verildiği gibidir.

Tablo 7. Uzaktan eğitim konulu lisansüstü tezlerin örnekleme yöntemleri

\begin{tabular}{ll}
\hline Örneklem türü* & Tez sayısı \\
\hline Amaçlı örnekleme & 20 \\
Uygun örnekleme & 20 \\
Seçkisiz örnekleme & 18 \\
Evrenin tamamına ulaşılan & 3
\end{tabular}

*Örnekleme türleri konusunda alanyazında farklı terimler kullanıldığından aynı olan örnekleme türleri başlıklar altında birleştirilmiştir. Amaçlı örnekleme maksimum çeşitlilik, ölçüt, kartopu örnekleme türlerini; uygun örnekleme kolay, elverişli örnekleme türlerini; seçkisiz örnekleme basit seçkisiz, random, rasgele, olasılıksız, raslantısal, basit tesadüfi örnekleme türleri (Büyüköztürk ve diğerleri, 2017; Can, 2014; Karasar, 2012) yerine kullanılmıştır.

Tablo 7 incelendiğinde örnekleme yöntemi belirtilen tezlerde en fazla amaçlı ve uygun örnekleme yöntemlerinin kullanıldığı tespit edilmiştir. Seçkisiz örnekleme 18 araştırmada kullanılmış ve evrenin tamamı üzerinden araştırma yürütüldüğünden 3 lisansüstü tezde örnekleme yöntemi belirtilmemiştir.

Salgın sürecinde hazırlanan uzaktan eğitim konulu lisansüstü tezlerin konularına ilişkin bulgular Tablo 8 'de verildiği gibidir.

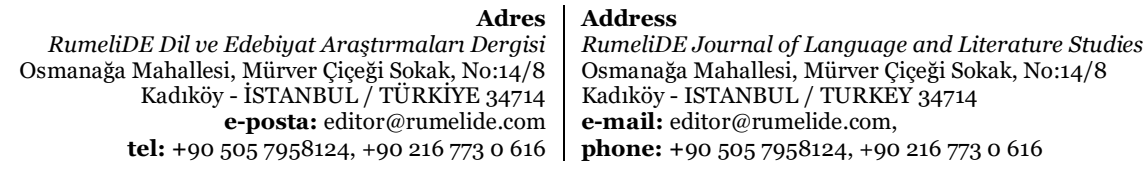


Tablo 8. Uzaktan eğitim ile ilgili lisansüstü tezlerin konularına göre dağ̆lımı

\begin{tabular}{llll}
\hline Konu & Tez sayısı & Konu & Tez sayısı \\
\hline Uzaktan eğitimde teknoloji & 32 & Psikoloji & 6 \\
Uzaktan eğitimde öğrenciler & 25 & Engelli bireyler & 3 \\
Uzaktan eğitim ve duyuşsal beceriler & 18 & Yöneticiler & 3 \\
Uzaktan eğitimde yöntem & 16 & Uzaktan eğitimde veliler & 2 \\
Uzaktan eğitimde öğretmenler & 15 & Uzaktan eğitimde ölçme & 2 \\
Uzaktan yabancı dil öğretimi & 10 & Uzaktan eğitimde tezler & 1 \\
\hline
\end{tabular}

Tablo 8 incelendiğinde lisansüstü tezlerde en fazla uzaktan eğitimde teknoloji konusunu ele aldığı görülmektedir. Eğitim süreci açısından öğretmen ve öğrenciler birlikte değerlendirildiğinde eğitim sürecini inceleyen 40 lisansüstü tez bulunmaktadır. Toplamda 12 farklı alanda uzaktan eğitim konusunda lisansüstü tez hazırlandığı tespit edilmiştir.

\section{Sonuç, tartışma ve öneriler}

Araştırmada ilk olarak 2020-2021 yllında hazırlanmış olan uzaktan eğitim konulu tezlerin yıla, yazım diline ve türüne göre dağılımı incelenmiştir. Sonuç olarak 2021 Eylül ayına kadar olan dönemde 2020 yılına göre daha fazla sayıda tez hazırlandığı, yayınlanan tezlerin çoğunun yüksek lisans tezi olduğu ve Türkçe olarak yazıldıkları tespit edilmiştir. Covid-19 salgın sürecinin uzaktan eğitim konusunu gündeme getirmesi ile birlikte bu konuyu ele alan araştırma ve tez sayılarında artış olması beklenen bir sonuçtur. Aydoğdu (2019) ve Delen (2021) benzer şekilde mobil öğrenme ve e-öğrenme kavramlarına ilişkin yapılan araştırma sayısında artış olduğunu ifade etmektedir. İncelenen tezlerin çoğunun yüksek lisans tezi olması yüksek lisans programlarının sayısının fazlalığından ve sürenin doktora eğitimine göre daha kısa olmasından kaynaklanıyor olabilir. Benzer araştırmalarda yüksek lisans çalışmalarının fazla olduğu (Delen 2021; Erdem Aydın ve diğerleri, 2019; Solmaz ve Gökçearslan, 2016) tespit edilmiştir. Araştırmada Türkiye'de yapılan lisansüstü tezleri kapsadığından bu tezlerin çoğunun Türkçe olarak hazırlanmış olması beklenen bir sonuçtur. Türkçe dışında sadece İngilizce olarak bu konuda tez hazırlandığı tespit edilmiştir.

İncelenen dönemde uzaktan eğitim konusunda en fazla tezin Gazi Üniversitesi bünyesinde hazırlandığı tespit edilmiştir. İkinci sırada ise Bahçeşehir Üniversitesi yer almaktadır. Delen (2021) benzer şekilde e-öğrenme konusunda Gazi Üniversitesi, Hacettepe Üniversitesi ve Anadolu Üniversitesi'nde daha fazla lisansüstü araştırma yapıldığını ifade etmektedir. Araştırma sonucunda hem devlet hem de vakıf üniversitelerinde uzaktan eğitim konusunda lisansüstü tezlerin hazırlandığının belirlenmesi önemlidir. Uzaktan eğitim konusunda hazırlanan tezlerin çoğu Eğitim Bilimleri Enstitüsü'nde yer alan programlarda hazırlanmıştır. Bu araştırmanın konusu uzaktan eğitim ve bununla ilişkili kavramlar olduğundan Eğitim Bilimleri Enstitüsü'nün öne çıkması mümkündür. Ancak Fen Bilimleri, Sağllk Bilimleri, Güzel Sanatlar Enstitüsü'nde hazırlanmış tezlerin bulunması farklı alanlarda uzaktan eğitim konusunun çalışıldığını göstermesi açısından önemlidir. Anabilim dalları açısından incelendiğinde Bilgisayar ve Öğretim Teknolojileri Eğitimi ile Eğitim Bilimleri Anabilim Dalı' nda daha fazla uzaktan eğitim konulu tez bulunmaktadır. Delen (2021) e-öğrenme konulu tezlerin çoğunun, Solmaz ve Gökçearslan (2016) mobil öğrenme konulu araştırmaların çoğunun Bilgisayar ve Öğretim Teknolojileri Eğitimi Anabilim Dalı'nda hazırlandığını ifade etmektedir. Bilgisayar ve Öğretim Teknolojileri Eğitimi Anabilim Dalı'nda daha fazla uzaktan eğitim konulu çalışmanın bulunmasının nedeni konunun teknoloji ile olan ilişkisi ile açıklanabilir.

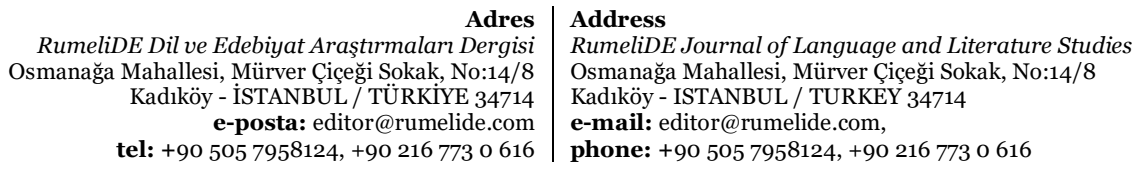


Araştırma yöntemleri açısından tezlere bakıldığında en fazla karma yöntem araştırmalarının yapıldığı belirlenmiştir. Aydoğdu (2019) mobil öğrenme konulu araştırmalarda karma ve nitel yöntemlerin kullanıldığını ifade etmektedir. Ancak Ilgaz (2018) çevrimiçi öğrenme araştırmalarında, Uygun ve Sönmez (2019) mobil öğrenme konulu çalışmalarda, Erdem Aydın ve diğerleri (2019) ve Gökmen ve diğerleri (2017) uzaktan eğitim konulu tezlerde nicel desenlerin kullanıldığını ifade etmektedir. İncelenen dönemde uzaktan eğitim konusunda hazırlanan tezlerde örneklem grubu olarak öğretmenler ve öğrenciler seçilmiştir. Aydoğdu (2019), Korucu ve Biçer (2019) mobil öğrenme konulu araştırmalarda; Delen (2021) e-öğrenme konulu tezlerde örneklem grubu olarak en fazla lisans öğrencilerinin seçildiğini ifade etmektedir. Eğitim konulu araştırmalarda örneklem grubu seçimi öğretim sürecinin temel unsurları olan öğretmen ve öğrenci gruplarından yana olabilir. Ayrıca araştırmanın örneklem grubuna erişim önemli bir ölçüt olduğundan öğretmen ve öğrenciler araştırmalarda sıkça yer alıyor olabilir. Örnekleme yöntemi belirtilen tezlerde amaçlı ve uygun örneklemenin daha sık olarak kullanıldığı belirlenmiştir. Benzer şekilde Gökmen ve diğerleri (2017) uzaktan eğitim konulu tezlerde örnekleme yöntemi belirtilmiş olanlarda en fazla uygun ve amaçlı örneklemenin kullanıldığını tespit etmiştir.

İncelenen tezlerde konu olarak uzaktan eğitim teknolojisi, uzaktan eğitimde öğrenciler, duyuşsal beceriler ile uzaktan eğitim ilişkisi, uzaktan eğitimde kullanılan yöntemler, uzaktan eğitimde öğretmenler, uzaktan yabancı dil öğretiminin ele alındığı tespit edilmiştir. Parlakkılıç ve Güldüren (2019) e-öğrenme konulu araştırmalarda içeriklerin araç ve içerik yönelimli konular olduğunu, ayrıca altyapı, öğretmen ve öğrenci konularının işlendiğini açlklamıştır. Aydoğdu (2019) mobil öğrenme konulu araştırmalarda alan bazında tıp ve dil eğitiminin öne çıktığını ifade etmektedir. Delen (2021) eöğrenme konulu tezlerde akademik başarı, e-öğrenme ortamlarının hazırlanması, tutum konularının incelendiğini tespit etmiştir. Buradan hareketle pek çok farklı konuda uzaktan eğitime ilişkin araştırma yapıldığı sonucuna varılabilir.

Araştırma sonuçlarından hareketle şu önerilerde bulunulabilir:

1. Uzaktan eğitim konusunda daha detaylı araştırmaların yapılabileceği doktora tezlerinin hazırlanması faydalı olacaktır.

2. Uzaktan eğitim tüm anabilim dallarını ilgilendiren bir konu alanı olduğundan farklı anabilim dallarında bu konuyu ele alan yeni çalışmalar hazırlanabilir.

3. Uzaktan eğitim hayatın her alanında kullanıldığından öğretmen ve öğrenci gruplarından farklı olarak seçilen örneklem gruplarında yeni araştırmalar hazırlanabilir.

4. Hazırlanan araştırmalarda yöntem, örneklem, örnekleme yönteminin belirtilmesi gereklidir.

\section{Kaynakça}

Anderson, T. ve Dron, J. (2011). Three generations of distance education pedagogy. International Review of Research in Open and Distributed Learning, 12(3), 80-97. https://doi.org/10.19173/irrodl.v12i3.890

Aydoğdu, H. (2019). Mobil öğrenme ile ilgili araşttrmalarm eğilimleri: Bir içerik analizi (Yayımlanmamış yüksek lisans tezi). Fırat Üniversitesi Eğitim Bilimleri Enstitüsü: Elazı̆̆.

Büyüköztürk, Ş., Çakmak, E. K., Akgün, Ö. E., Karadeniz, Ş., Demirel, F. (2017). Bilimsel araştırma yöntemleri. Ankara: Pegem A.

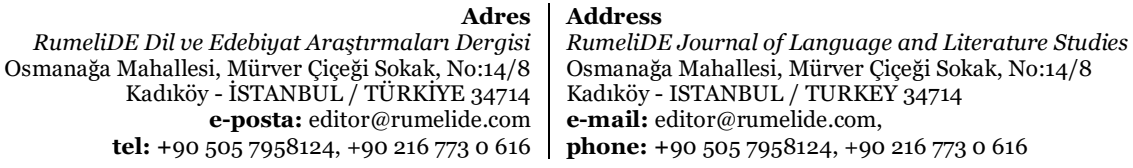


Can, A. (2014). SPSS ile bilimsel araştırma sürecinde nicel veri analizi. Ankara: Pegem A.

Delen, A. (2021). Türkiye'de e-öğrenme ortamlarına ilişkin yapılan araşttrmalardaki eğilimler: 20042020 dönemi tezlerin incelenmesi (Yayımlanmamış yüksek lisans tezi). Necmettin Erbakan Üniversitesi Eğitim Bilimleri Enstitüsü: Konya.

Erdem Aydın İ., Kaya S., İşkol S., İşcan A., (2019). Anadolu Üniversitesi uzaktan eğitim bölümünde yayınlanmış yüksek lisans ve doktora tezlerinin içerik analizi. Yükseköğretim ve Bilim Dergisi, 9(3). doi: 430-441. 10.5961/jhes.2019.343

Erzen, E. ve Ceylan, M. (2020). Covid-19 salgını ve uzaktan eğitim: Uygulamadaki sorunlar. Ekev Akademi Dergisi, 24(84), 229-262.

Fojtík, R.(2018). Problems of distance education. ICTE Journal, 7(1), 14-23. doi: 10.2478/ijicte-20180002

Gökmen, Ö. F., Uysal, M., Yaşar, H., Kırksekiz, A., Güvendi, G. M., Horzum, M. B. (2017). Türkiye'de 2005-2014 yılları arasında yayınlanan uzaktan eğitim tezlerindeki yöntemsel eğilimler: Bir içerik analizi. Eğitim ve Bilim, 42(189), 1-25. http://dx.doi.org/10.15390/EB.2017.6163

Gunawardena, C. N. ve McIsaac, M. S. (2013). Distance education. Spector, M., Merrill, M. D., Elen, J., Bishop, M. J. (Ed.), Handbook of research on educational communications and technology, içinde (s. 361-401). İngiltere: Routledge.

Huang, R. H., Liu, D. J., Tlili, A., Yang, J. F., Wang, H. H. (2020). Handbook on facilitating flexible learning during educational disruption: The Chinese experience in maintaining undisrupted learning in COVID-19 outbreak. Erişim adresi: http://www.alecso.org/nsite/images/pdf/1-42.pdf

Ilgaz, H. (2018). Bireysel farklılıklar kapsamında çevrimiçi öğrenme araştırmalarına ilişkin sistematik bir derleme. Kuramsal Ĕ̆itimbilim Dergisi, 11(4),1003-1018.

Karadağ, E., Çiftçi, S. K., Gök, R., Su, A., Ergin Kocatürk, H., Çiftçi, Ş. S. (2021). Covid-19 pandemisi sürecince üniversitelerin uzaktan eğitim kapasiteleri. Üniversite Araştırmaları Dergisi, 4(1), 822. doi:10.26701/uad.874799

Karasar, N. (2012). Bilimsel araşttrma yöntemi. Ankara: Nobel.

Keegan, D. (2013). Foundations of distance education third edition. İngiltere ve ABD: Routledge.

Korucu, A. T. ve Biçer, H. (2019). Mobil öğrenme: 2010-2017 çalışmalarına yönelik bir içerik analizi. Trakya Ĕ̆itim Dergisi, 9(1), 32-43.

Lee, H. J. ve Rha, I. (2009). Influence of structure and interaction on student achievement and satisfaction in web-based distance learning. Educational Technology \& Society, 12(4), 372-382.

Milli Eğitim Bakanlığı. (2021). EBA, 1.2 milyar tıklanma sayısıyla kendi rekorunu güncelledi. Erişim adresi: $\quad$ https://www.meb.gov.tr/eba-12-milyar-tiklanma-sayisiyla-kendi-rekorunuguncelledi/haber/20862/tr

Moore, M. G. ve Thompson, M. M. (1990). The Effects of Distance Learning: A Summary of Literature. Erişim adresi: https://files.eric.ed.gov/fulltext/ED330321.pdf

Özer, M. ve Suna, H. E. (2020). COVID-19 salgını ve eğitim. Şeker, M., Özer, A., Korkut, C. (Ed.), Küresel salgının anatomisi: insan ve toplumun geleceği, içinde (s. 171-192). Ankara: Türkiye Bilimler Akademisi.

Özonur, M. (2021). Uzaktan eğitim ve öğretim. Göçer, A. (Ed.), Türkçenin uzaktan öğretimi ve öğrenimi, içinde (s. 25-49). Ankara: Pegem A.

Parlakkılıç, A. ve Güldüren, C. (2019). Türkiye'deki e-öğrenme araştırmalarında yönelimler. International Journal of Contemporary Educational Studies, 5(1), 19- 29.

Persico, D., Manca, S., Pozzi, F. (2014). Adapting the technology acceptance model to evaluate the innovative potential of e-learning systems. Computers in Human Behavior, 30, 614- 622.

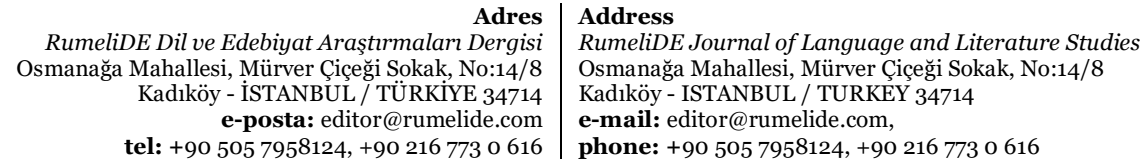


Sezgin, S. ve Frrat, M. (2020). Covid-19 pandemisinde uzaktan eğitime geçiş ve dijital uçurum tehlikesi. Açıöğretim Uygulamaları ve Araştırmaları Dergisi, 6(4), 37-54. https://dergipark.org.tr/en/ download/article-file/1195678

Simonson, M., Zvacek, S. M., Smaldino, S. (2019). Teaching and learning at a distance: Foundations of distance education. Language Learning \& Technology, 4(1), 16-19. https://core.ac.uk/reader/84320820

Solmaz, E. ve Gökçearslan, Ş. (2016). Mobil öğrenme: Lisansüstü tezlere yönelik bir içerik analizi çalsşması. 10. Uluslararası Bilgisayar ve Öğretim Teknolojileri Sempozyumu'nda (ICITS), Rize.

Threlkeld, R. ve Brzoska, K. (1994). Research in distance education. Willis, B. (Ed.), Distance education strategies and tools, içinde (s. 41-66). ABD: Educational Technology Publications.

Uygun, D. ve Sönmez, A. (2019). Mobil öğrenme üzerine güncel çalışmalarla ilgili bir içerik analizi. Açıöğretim Uygulamaları ve Araştırmaları Dergisi, 5(1), 53-69.

Wedemeyer, C. (1981). Learning at the back-door. ABD: University of Wisconsin

World Health Organisation. (2021). WHO Director-General's statement on IHR Emergency Committee on Novel Coronavirus (2019-nCoV). Erişim adresi: https://covid19.who.int/

Yakar, L. ve Yıldırım Yakar, Z. (2021). Eğitim fakültesi öğrencilerinin uzaktan eğitime karşı tutumlarının ve e-öğrenmeye hazır bulunuşluklarının incelenmesi. Mersin Üniversitesi Ĕ̆gitim Fakültesi Dergisi, 17(1), 1-21. doi:10.17860/mersinefd.781097

Yamamoto, G. T. ve Altun, D. (2020). Coronavirüs ve çevrimiçi (Online) eğitimin önlenemeyen yükselişi. Journal of University Research, 3(1), 25-34. https://doi. org/10.26701/uad.711110

Adres
RumeliDE Dil ve Edebiyat Araşturmaları Dergisi Osmanağa Mahallesi, Mürver Çiçeği Sokak, No:14/8 Kadıköy - İSTANBUL / TÜRKIYE 34714 e-posta: editor@rumelide.com tel: +90 $5057958124,+902167730616$
Address

RumeliDE Journal of Language and Literature Studies Osmanağa Mahallesi, Mürver Çiçeği Sokak, No:14/8

Kadıköy - ISTANBUL / TURKEY 34714

e-mail: editor@rumelide.com,

phone: +90 5057958124, +90 2167730616 